\title{
Endophytic fungi from tropical ethnoveterinary plants and their antibacterial efficacy against Pasteurella multocida Capsular Type A strain
}

\author{
Archana Nath \& Santa Ram Joshi* \\ Microbiology Laboratory, Department of Biotechnology and Bioinformatics, North-Eastern Hill University, \\ Shillong-793022, India; srjoshi2006@yahoo.co.in, archananath3@gmail.com \\ * Correspondence
}

Received 06-IV-2015. Corrected 10-I-2016. $\quad$ Accepted 05-II-2016.

\begin{abstract}
Pasteurella multocida is an important veterinary pathogen causing infections in animals and birds. Nowadays, different reports have described the severity of infections, increasing resistance of micro-organisms to antibiotics, and the contribution of ethnoveterinary practices towards the treatment of various ailments of animals. The aim of the present study was to investigate the antibacterial efficacy of the ethanolic extracts of endophytic fungi against $P$. multocida Capsular Type A strains. A total of six endophytic fungi were isolated from two tropical ethnoveterinary plants: Garcinia xanthochymus H. and Polygonum chinense L. The ethanolic extracts of the endophytic fungi were subjected to in vitro antimicrobial activity by the well diffusion method. Besides, we evaluated the treatment of mice with the potent fungal extract and observed the effects in different organs under electron microscopy. Our results showed that four fungi had antimicrobial activity against the selected pathogen. The best antibacterial activity was showed by the extract of the endophytic fungi, Glomerella magna isolated from $G$. xanthochymus, with a minimum inhibitory concentration of $46.9 \mu \mathrm{g} / \mathrm{mL}$ and minimum bactericidal concentration of $750 \mu \mathrm{g} / \mathrm{mL}$. Treatment of mice with the potent fungal extract caused a considerable inhibitory effect on the pathogen growth in vital organs, results that was also confirmed by histopathological studies made by scanning electron microscopy. The present findings indicated that the endophytic fungi $G$. magna has the potential to provide an effective treatment against infections caused by Pasteurella multocida. However, the isolation of bioactive components needs further investigation. Rev. Biol. Trop. 64 (2): 733-745. Epub 2016 June 01.
\end{abstract}

Key words: ethnoveterinary plants, endophytic fungi, antibacterial, Pasteurella multocida, scanning electron microscopy.

Livestock industries play an important role especially among the rural folks of many developing countries throughout the world. Livestock poor health constraints the development of this industry, and impacts the economy of a country. Pasteurella multocida is recognized to cause many important diseases in animals and birds and represents an important veterinary pathogen. Strains belonging to Pasteurella species are currently classified into five serogroups (A, B, D, E, F) based on their capsular composition, and 1 - 16 somatic serovars (Tabatabaei et al., 2002). Pasteurella is sometimes zoonotic in nature, causing infection in humans, remitted due to bites or scratches from domestic pets. Certain serotypes of $P$. multoci$d a$ cause atrophic rhinitis, an infectious disease of swine, characterized by serous to mucopurulent nasal discharge, shortening or twisting of the snout, atrophy of the turbinate (conchal) bones and reduced productivity (World Assembly of Delegates of the OIE, 2012). A severe progressive form is mostly caused by toxigenic isolates of $P$. multocida, most commonly capsular types D or A, alone or in combination with Bordetella bronchiseptica.

In a vast country like India, rural areas are invariably out of reach of proper veterinary 
healthcare, which compels the livestock owners to depend on ethnoveterinary plants for treatment of livestock ailments. Ethno veterinary medicine (EVM) is practiced for its efficacy, low cost, availability and ease of administration, in comparison to other alternatives (Adamu, Naidoo \& Eloff, 2014; Lulekal, Asfaw, Kelbessa, \& Damme, 2014; Yigezu, Haile, \& Ayen, 2014). In the present study, ethnoveterinary plants, Garcinia xanthochymus H. and Polygonum chinense L. which are widely used by the local livestock farmers of Northeast India for curing diarrhea and dysentery in animals, were evaluated for their antimicrobial activity along with the associated fungi. There are reports on biological activities of $G$. xanthochymus as antibacterial, antimalarial, cytotoxicity, analgesic, antioxidant, antiviral, neurotrophic, inhibition of cyclooxygenase, antifungal and gastroprotective activity (Muharni, Elfita, \& Amanda, 2011, Ismail et al., 2012, Maharajan, Rajendran, Thomas, \& Aravindhan, 2012). However, there are no reports on biological activities of endophytic fungi associated with these plants.

The North-Eastern region of India in the tropical and sub-tropical belts of Eastern Himalayan range, is blessed with a wide range of physiography and ecoclimatic conditions. It is one of the biodiversity hotspots (Myers, Mittermeier, Mittermeier, de Fonseca, \& Kent, 2000) and is rich in diverse groups of flora and fauna, which has attracted attention of researchers over the years but the microbial groups have not been explored to a great extent for their applications. Northeast India in the Eastern Himalayan range is lying between $\left(20^{\circ} 35^{\prime}\right.$ 37.2624" N -78 57' 46.368" E), and sprawling over 262379 km² (Lyngwi, Koijam, Sharma, $\&$ Joshi, 2013), and covers a major area under tropical and sub-tropical belts.

Microorganisms have almost universal presence in plants. Endophytes are microbes which reside in the internal living tissues of plant without causing any harm to the host (Bacon \& White, 2000). Endophytes are known to produce some bioactive secondary metabolites which protect their host from infectious agents and adverse conditions, and produce pharmacologically active compounds (Strobel, Daisy, Castillo, \& Harper, 2004; Zhang, Song, \& Tan, 2006; Verma, Kharmar, \& Strobel, 2009). Though there are reports on endophytic fungi associated with ethnomedicinal plants (Bhagobaty, Joshi, \& Kumar, 2010, Bhagobaty \& Joshi, 2011a, Nath \& Joshi, 2013), reports on the bioactivity of endophytic fungi isolated from ethnoveterinary plants are very scarce (Nath \& Joshi, 2014). The present study thus was an attempt to assess the comparative efficacy of ethnoveterinary plants as well as associated fungi, for exploring the endophytic fungi as alternative sources of treatment against animal diseases. The study reports the antimicrobial efficacy of endophytic fungal extract both in vitro and in vivo against Pasteurella multocida capsular type A strain.

\section{MATERIALS AND METHODS}

Collection of plant samples: The ethnoveterinary plants, Garcinia xanthochymus H. and Polygonum chinense L. were collected in October 2011 (rainy season) from the tribal belts located in the tropical regions of Northeast India, after a preliminary survey on their usage from the local livestock farmers. Healthy plants were collected in sterile polyethylene bags, brought to the laboratory and kept at $4{ }^{\circ} \mathrm{C}$ until further processing.

Surface sterilization and isolation of endophytic fungi: The plant samples were washed properly in running tap water and were cut into pieces of $0.5-1 \mathrm{~cm}$ long. The explants were immersed in $70 \%$ ethyl alcohol for 1 min, followed by immersion in $4 \%$ sodium hypochlorite solution for $3 \mathrm{~min}$, and then in 70 $\%$ ethyl alcohol for $1 \mathrm{~min}$. These were finally rinsed with sterile distilled water and blotted dry. The plant parts were then placed on Potato Dextrose Agar (PDA) supplemented with streptomycin $(100 \mu \mathrm{g} / \mathrm{mL})$ and incubated at $25{ }^{\circ} \mathrm{C}$, until some growth from the explants was observed (Petrini, 1986). The fungi that grew out from the segments were isolated by 
transferring the hyphal tips to fresh PDA plates without antibiotics.

\section{Molecular characterization of endophyt-} ic fungi: The mycelia of fungi grown in Potato Dextrose Broth (PDB) at $25{ }^{\circ} \mathrm{C}$ for 3-5 days were harvested and crushed with a sterilized pestle in a mortar under liquid nitrogen. The genomic DNA was then obtained by using the HiPurA fungal DNA isolation kit (Himedia). DNA samples were stored at $4{ }^{\circ} \mathrm{C}$ for immediate use and at $-20^{\circ} \mathrm{C}$ for long-term storage. The primers ITS1 and ITS4 were used to amplify the internal transcribed spacer region (ITS) of the nuclear ribosomal RNA operon, including the $3^{\prime}$ end of the $18 \mathrm{~S}$ rRNA, ITS1 region, the 5.8S rRNA gene; ITS2 region and the $5^{\prime}$ end of the 28S rRNA gene (Bhagobaty \& Joshi, 2011b). The PCR reaction mixture comprised of $10 \mu \mathrm{L}$ fungal DNA, $5 \mu \mathrm{L} 10 \times$ PCR buffer, $1.5 \mu \mathrm{L}$ of $50 \mathrm{mM} \mathrm{MgCl}, 1 \mu \mathrm{L}$ of $10 \mathrm{mM} \mathrm{dNTP \text {, }}$ $0.25 \mu \mathrm{L}$ Taq polymerase, $40 \mathrm{pM}$ each of the forward and the reverse primers in a total reaction volume of $50 \mu \mathrm{L}$. Reaction consisted of an initial denaturation of $94{ }^{\circ} \mathrm{C}$ for 5 min followed by thirty cycles of $94{ }^{\circ} \mathrm{C}$ for $1 \mathrm{~min}, 52^{\circ} \mathrm{C}$ for 30 sec, $72{ }^{\circ} \mathrm{C}$ for $1 \mathrm{~min}$, and final extension for 10 min (Bhagobaty \& Joshi, 2011b). PCR was carried out in a GeneAmp 9700 Thermal Cycler (Applied Biosystems, Foster City, CA, USA). Amplification of DNA were confirmed by running the product in $1.5 \%$ agarose gel and the amplified products sequenced using Big Dye Terminator cycle sequencing kit v.3.1 (Applied Biosystems, USA) deploying the standard protocol and an automated Genetic Analyzer ABI 3130XL (Applied Biosystems, USA). Sequences obtained from the amplified products were then analyzed with the sequences obtained from NCBI database using BLAST, aligned using the Clustal W program and phylogenetic tree was constructed using MEGA 4.1 software (Tamura et al., 2011). The sequences were deposited to the NCBI database and accession numbers obtained.

Preparation of plant extract: The collected plants were first washed properly with distilled water and then dried in an oven at $50{ }^{\circ} \mathrm{C}$ for $72 \mathrm{~h}$ with forced air, after which the dried plants were grounded into a fine powder using a clean pestle and mortar. Dried samples (approximately $100 \mathrm{~g}$ ) were soaked in ethanol $(300 \mathrm{~mL})$ for 4 days at room temperature $(25 \pm$ $2^{\circ} \mathrm{C}$ ) with an intermittent stirring to allow the powder to fully dissolve in the $70 \%$ ethanol. The mixture was then filtered through Whatman No. 1 paper. The filtrate was then concentrated under vacuum using a rotary evaporator. The dried crude extracts were finally dissolved in dimethylsulfoxide (DMSO) to make a final concentration of $1 \mathrm{mg} / \mathrm{mL}$ and then sterilized by filtration using a $0.22 \mu \mathrm{m}$ membrane for antimicrobial assay (Vijayarathna et al., 2012). The resultant extract was kept at $4{ }^{\circ} \mathrm{C}$ for further analysis.

Extraction of fungal crude extract: Fungal hyphae were cut into small pieces and were inoculated in a conical flask containing PDB. The flask was then incubated at $25{ }^{\circ} \mathrm{C}$ for $10-15$ days. After obtaining proper growth, the broth was filtered through muslin cloth to separate the mycelia from the broth. The filtrate was then mixed with twice the volume of $70 \%$ ethyl alcohol and filtered through Whatman filter paper No. 1. The solvent phase was evaporated and the residue was dried under rotary evaporator at $50{ }^{\circ} \mathrm{C}$ (Nath, Chattopadhyay \& Joshi, 2013). The residue was then dissolved in $50 \%$ DMSO prior to use.

In vitro antimicrobial activity by well diffusion method: The antimicrobial activity of the ethanolic extract of endophytic fungi was tested against the Pasteurella multocida capsular type A, Pig strain collected from the Microbiology Department, College of Veterinary Science, Assam, India. Test bacterium was subcultured on Brain Heart Infusion Broth (BHI) for $48 \mathrm{~h}$. The antimicrobial test was carried out on Mueller Hinton Agar (MHA) plates. One mililitre of broth containing the test micro-organisms was swapped on the agar plates. Seven $\mathrm{mm}$ wells were made on the agar plates using the sterile cork borer in which 50 
$\mu \mathrm{L}$ of crude ethanolic extract was introduced. After incubating at $37{ }^{\circ} \mathrm{C}$ for $24 \mathrm{~h}$, the plates were observed for zone of inhibition (Nath, Raghunatha, \& Joshi, 2012).

Determination of minimum inhibitory concentration (MIC) and minimal bactericidal concentration (MBC): MIC was determined on 96 well microtitre plate by the microdilution method according to NCCLS protocol (NCCLS, 1990; NCCLS, 2002). A total of $100 \mu \mathrm{L}$ of Mueller Hinton Broth were put in each well, followed by serial dilution of the stock solution of extract to get the concentrations in the range of $1.5-1500 \mu \mathrm{g} / \mathrm{mL}$. Then $100 \mu \mathrm{L}$ of broth containing bacterial suspension $\left(5 \times 10^{6} \mathrm{CFU} / \mathrm{mL}\right)$ was added to all the wells. The plates were then sealed properly to avoid dehydration of bacteria and were incubated at $37^{\circ} \mathrm{C}$ for $24 \mathrm{~h}$. After incubation, $20 \mu \mathrm{L}$ of $0.5 \%$ of 2, 3-5 Triphenyl tetrazolium chloride (TTC) aqueous solution was added to each well of microtitre plate (Savaroglu et al., 2011). The plates were again incubated at $37{ }^{\circ} \mathrm{C}$ for $1 \mathrm{~h}$ and then were checked for any visual color change. Any change in color from purple to pink indicated the bacterial growth. MIC was taken as the lowest concentration which did not show any visual color change. Bacterial cells from the microtitre plate were subcultured on fresh BHI plates and incubated at $37{ }^{\circ} \mathrm{C}$ and $\mathrm{MBC}$ determined after $24 \mathrm{~h}$ (Akinyemi, Oladapo, Okwara, Ibe, \& Fasure, 2005). The plates showing no growth were considered as the MBC of the extract or the antibiotic Amoxicillin used.

Experimental animals: Female Swiss albino mice were obtained from Pasteurs Institute, Shillong, Meghalaya. Mice selected for the experiments were of 25-30 g of weight and were aged between 5-6 weeks. The welfare of the animals and the experimental procedures were in strict accordance with the institutional ethical committee. They were kept in hygienic and temperature controlled room under a $12 \mathrm{~h}$ light $12 \mathrm{~h}$ dark cycle, with free access to commercial mice food (Amrut, India) and $a d$ libitum water. The mice were acclimatized for one week before the experiments were carried out.

Acute toxicity studies: Before the experiment, the animals were starved for $24 \mathrm{~h}$ with free access to ad libitum water. Acute oral toxicity test was performed as per OECD-423 guidelines (Ecobichon, 1997). The extracts were administered to the animal groups at a dose level of $10 \mathrm{mg} / \mathrm{kg}$ body weight and the group was observed for 2 weeks. If there is mortality in $2-3$ mice among a group of 6 mice, the dose is considered as toxic dose, and if only one animal is dead, then the same dose is repeated again for the confirmation of toxic dose. If the animals did not show any mortality, the different animal groups ( 5 in each group) were administered with the doses of extract as $100,250,500,1000 \mathrm{mg} / \mathrm{kg}$ body weight. Then the animals were observed for any toxicity / mortality for the next 14 days.

Study of antibacterial activity in mice: The animals were divided into five groups consisting of five animals in each group: Control (Gp1) which received only sterile distilled water. P. multocida was grown overnight in BHI broth, centrifuged and washed in phosphate buffered saline and finally diluted in PBS to achieve $\sim 1 \times 10^{5} \mathrm{CFU} / \mathrm{mL}$. A volume of 0.1 $\mathrm{mL}$ of the bacterial suspension was administered to the different groups (Gp 2-Gp 5) of animals through the intraperitoneal (IP) route (Tabatabaei et al., 2002, Sweeney, Quesnell, Tiwari, LeMay, \& Watts, 2013). After $1 \mathrm{~h}$ of post infection, the animal groups (Gp 3, Gp 4) were administered orally with the fungal extract at doses of 100 and $250 \mathrm{mg} / \mathrm{kg}$ body wt respectively for 8 successive days. Amoxicillin at a concentration of $10 \mathrm{mg} / \mathrm{kg}$ body weight was administered orally to the last group of animals (Gp 5). Different animal groups were checked for any change in body weight and body temperature every alternate day.

Assessment of bacterial infection in vital organs: To assess the efficacy of fungal extract 
treatment on the establishment of infection in animals, two animals from each group were sacrificed on day 4 after infection and the rest of the animals after the end of the experiment i.e. on day 8. Different organs from the sacrificed animals were collected aseptically, homogenized properly in sterile PBS and were swapped on the Brain Heart Infusion agar for the re-isolation of the organism to observe the number of viable bacteria (Owais, Sharad, Shehbaz, \& Saleemuddin, 2005).

\section{Ultrastructural analysis of tissues under scanning electron microscope (SEM): The} liver and spleen tissues were cut into small segments and were fixed in $2.5 \%$ gluteraldehyde in $0.1 \mathrm{M}$ cacodylate buffer ( $\mathrm{pH} 7.2$ ) for $12 \mathrm{~h}$. Gluteraldehyde was drained out carefully and washed thrice for $1 \mathrm{~h}$ in $0.1 \mathrm{M}$ cacodylate buffer. The samples were dehydrated with acetone series $(50,70,80,90,95$ and $100 \%)$ and drying was done with TMS (Trimethyl silane). Tissues were immersed twice in TMS for 10 min at $4{ }^{\circ} \mathrm{C}$ and were brought to room temperature for drying. Finally, samples were sputter coated with a thin layer of gold - palladium and scanned under SEM.

Phytochemical screening: Qualitative and quantitative analysis of the ethanolic extracts were carried out using standard procedures (Sofowora, 1993; Edeoga, Okwu, \& Mbaebie, 2005).

Gas chromatography analysis of the extracts: Gas chromatographic analysis was carried out in Gas chromatograph (Bruker 436) using scion and column (non polar) $0.25 \mathrm{~mm}$ filled methyl polyphylosane. The carrier gas was $\mathrm{N}_{2}$ with a constant flow $1 \mathrm{~mL} / \mathrm{min}$. Injected volume was $1 \mu \mathrm{L}$. Phenol was detected by flame-ionization detector (FID). Temperature of injection, on column oven and on detector was $240{ }^{\circ} \mathrm{C}$ with the initial detector at $100{ }^{\circ} \mathrm{C}$ which was then set to $240{ }^{\circ} \mathrm{C}$ at a rate of 15 ${ }^{\circ} \mathrm{C} / \mathrm{min}$ and $250{ }^{\circ} \mathrm{C}$, respectively. The chromatogram was measured by $\mathrm{PC}$ and evaluated by compass CDS. The concentration of free carbolic acid in the sample was determined by means of the calibration curve. Methanolic solutions of carbolic acid with concentration of 3 ppm were used as standard.

\section{RESULTS}

Isolation of endophytic fungi: A total of six endophytic fungi were isolated from different parts of the two ethnoveterinary medicinal plants, $G$. xanthochymus $\mathrm{H}$. and $P$. chinense L., out of which, four were isolated from the stems. Based on morphology, colour and genomic characterization using BLAST search of rDNA-ITS sequence, the endophytic fungi were identified as Glomerella magna, Epicoccum sorghi, Corynespora cassiicola, two strains of Colletotrichum gloeosporioides and Paecilomyces variotii (Fig. 1). The rDNA-ITS sequence were submitted to the NCBI GenBank and accession numbers obtained (KM282289, KF928279, KF928286, KM282291, KF928283 and KF928281).

Antimicrobial activity: Among the six endophytic fungi, only four showed antibacterial activity against $P$. multocida. The highest zone of inhibition was shown by the ethanolic extract of G. magna followed by E. sorghi. The plant extract of $G$. xanthochymus also showed antibacterial activity better than the extract of P. chinense (Table 1).

Minimum inhibitory concentration (MIC) and minimal bactericidal concentration (MBC): MICs of the extracts were found to range from $46.9-375 \mu \mathrm{g} / \mathrm{mL}$ (Table 1). Ethanolic extract of G. magna showed the most potent inhibition of $P$. multocida (MIC $46.9 \mu \mathrm{g} / \mathrm{mL}$ and MBC $750 \mu \mathrm{g} / \mathrm{mL}$ ). However, the reference drug Amoxicillin was found to show higher antibacterial activity as compared to plants and fungal extracts.

Acute toxicity test: The potency of the fungal isolate $G$. magna in the in vitro assay led to the in vivo evaluation of its antibacterial activity. When administered up to a dose 


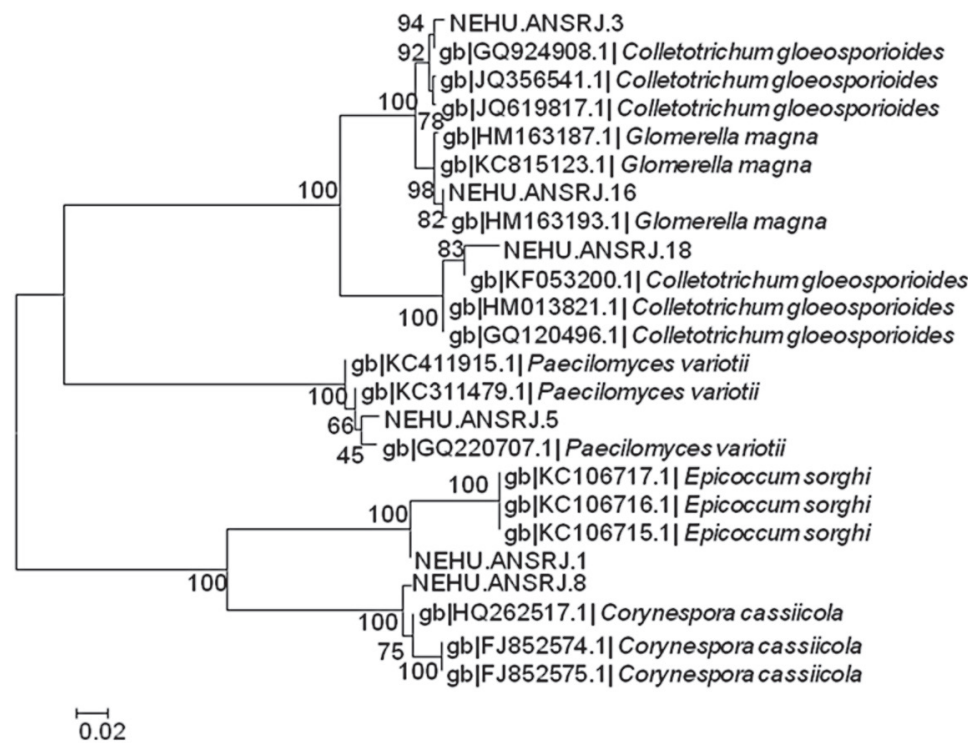

Fig. 1. Phylogenetic tree of the endophytic fungal isolates constructed with MEGA 4 software using the neighbor joining method.

TABLE 1

Inhibition zone, Minimum inhibitory concentration and Minimum bactericidal concentration of the ethanolic extract of different endophytic fungal and plant extracts

\begin{tabular}{|c|c|c|c|c|}
\hline & $\begin{array}{c}\text { Ethanolic Extract } \\
(5 \mathrm{mg} / \mathrm{mL})\end{array}$ & $\begin{array}{l}\text { Inhibition Zone } \\
(\mathrm{mm})\end{array}$ & $\begin{array}{c}\text { MIC } \\
(\mu \mathrm{g} / \mathrm{mL})\end{array}$ & $\begin{array}{c}\mathrm{MBC} \\
(\mu \mathrm{g} / \mathrm{mL})\end{array}$ \\
\hline \multirow[t]{6}{*}{ Endophytic fungi } & Glomerella magna (NEHU. ANSRJ.16) & 24 & 46.9 & 750 \\
\hline & Epicoccum sorghi (NEHU. ANSRJ.1) & 21 & 93.75 & 750 \\
\hline & Corynespora cassicola (NEHU. ANSRJ.8) & 12 & 375.0 & 1500 \\
\hline & Colletotrichum gloeosporioides (NEHU. ANSRJ.18) & 16 & 93.75 & 750 \\
\hline & Paecilomyces variotii (NEHU. ANSRJ.5) & - & - & - \\
\hline & Colletotrichum gloeosporioides (NEHU. ANSRJ.3) & - & - & - \\
\hline \multirow[t]{2}{*}{ Plants } & Garcinia xanthochymus $\mathrm{H}$ & 17 & 93.75 & 750 \\
\hline & Polygonum chinense L. & 10 & 375.0 & $>1500$ \\
\hline Antibiotics & Amoxicillin & 30 & 11.8 & 187.5 \\
\hline
\end{tabular}

of $1000 \mathrm{mg} / \mathrm{kg}$ body wt., the ethanolic extract of G. magna did not show any mortality in animals during the observation period of 14 days. However, tachycardia was observed in the animal groups administered with the extract doses of 500 and $1000 \mathrm{mg} / \mathrm{kg}$ body wt. Hence, doses of 100 and $250 \mathrm{mg} / \mathrm{kg}$ body weight were considered safe for the experiment.

Antibacterial activity in animals: After $12 \mathrm{~h}$ of infection, the animals showed febrile condition and mild cyanosis of the extremities. The experimental animals became depressed and were seen gathered together in groups in one side of the cage. They were reluctant to take food, water and make any movements in the cages. After $8 \mathrm{~h}$ of infection, two mice from control group were dead and the rest showed cyanosis of the extremities without any movement. After every two days, different animal groups were checked for any change in their body weight, and body temperature. The 
TABLE 2

Pasteurella multocida count (CFU/g of tissue) in vital organs of mice model treated with ethanolic extract of Glomerella magna and antibiotics

\begin{tabular}{|c|c|c|c|c|}
\hline \multirow[t]{2}{*}{ Animal Groups } & \multicolumn{2}{|c|}{$\begin{array}{c}\text { Bacterial load in liver } \\
\text { (CFU/g of tissue) post infection }\end{array}$} & \multicolumn{2}{|c|}{$\begin{array}{c}\text { Bacterial load in spleen } \\
\text { (CFU/g of tissue) post infection }\end{array}$} \\
\hline & 4 days & 8 days & 4 days & 8 days \\
\hline Gp1 (Control) & $\mathrm{ND}^{1}$ & $\mathrm{ND}^{1}$ & $\mathrm{ND}^{1}$ & $\mathrm{ND}^{1}$ \\
\hline Gp 2 (Infected) & $1.37 \times 10^{7}$ & $2.94 \times 10^{7}$ & $1.26 \times 10^{7}$ & $2.34 \times 10^{7}$ \\
\hline $\begin{array}{l}\text { Gp } 3 \text { (Infected + crude extract } \\
\text { at } 100 \mathrm{mg} / \mathrm{kg} \text { body wt. of animal) }\end{array}$ & $2.17 \times 10^{4}$ & $2.14 \times 10^{4}$ & $2.21 \times 10^{4}$ & $1.11 \times 10^{4}$ \\
\hline $\begin{array}{l}\text { Gp } 4 \text { (Infected + crude extract } \\
\text { at } 250 \mathrm{mg} / \mathrm{kg} \text { body wt. of animal) }\end{array}$ & $1.3 \times 10^{3}$ & $1.1 \times 10^{3}$ & $1.8 \times 10^{3}$ & $1.0 \times 10^{3}$ \\
\hline $\begin{array}{l}\text { Gp } 5 \text { (Infected }+ \text { Amoxicillin } \\
\text { at } 10 \mathrm{mg} / \mathrm{kg} \text { body wt. of animal })\end{array}$ & $1.0 \times 10^{2}$ & $1.2 \times 10^{2}$ & $1.2 \times 10^{2}$ & $1.1 \times 10^{2}$ \\
\hline
\end{tabular}

$\mathrm{ND}^{1}=$ Not detected

animals belonging to Gp 2 showed gradual increase in body temperature and weight loss. Experimental animals in Gp 3 showed initial increase in temperature until $48 \mathrm{~h}$, but later, the temperature dropped down without any weight loss. Group 4 and group 5 did not show any increase in temperature and weight loss. Bacterial load in the vital organs like liver and spleen were calculated and animals in Gp 4 and Gp 5 showed lower bacterial count in the affected organs as compared to the infected Gp-2 and Gp 3 treated with crude extracts (Table 2).

Ultrastructural analysis of vital organs using SEM: Tissues of liver and spleen of different groups of animals analyzed under SEM for any pathological changes revealed marked histological changes in the vital organs (Fig. 2, Fig. 3).

Phytochemical screening: Phytochemical screening of the crude extracts showed the presence of phenol and tannins in all the fungal and plant extracts. The extract of G. magna showed the presence of all the phytochemicals except flavonoids and saponins (Table 3 ).

GC analysis of the extract: The GC analysis was carried out with nitrogen, hydrogen and zero air at a constant flow rate of $1 \mathrm{~mL} /$ min. A non-polar column was used for the separation. The crude extract of G. magna (NEHU. ANSRJ.16) showed the retention time (RT) of 5.3 min which is similar to the RT of standard

TABLE 3

Phytochemical screening of the crude ethanolic extracts of endophytic fungi and plants

\begin{tabular}{|c|c|c|c|c|c|c|c|}
\hline & \multirow{2}{*}{ Ethanolic extract ( $5 \mathrm{mg} / \mathrm{mL})$} & \multicolumn{6}{|c|}{ Phytochemicals } \\
\hline & & Alkaloids & Flavonoids & Steroids & Phenol & Tannin & Saponin \\
\hline \multirow{6}{*}{$\begin{array}{l}\text { Endophytic } \\
\text { fungi }\end{array}$} & Glomerella magna (NEHU. ANSRJ.16) & - & ++ & + & +++ & ++ & - \\
\hline & Epicoccum sorghi (NEHU. ANSRJ.1) & - & ++ & + & ++ & + & + \\
\hline & Corynespora cassicola (NEHU. ANSRJ.8) & + & ++ & - & ++ & + & - \\
\hline & Colletotrichum gloeosporioides (NEHU. ANSRJ.18) & ++ & - & ++ & +++ & + & + \\
\hline & Paecilomyces variotii (NEHU. ANSRJ.5) & - & ++ & - & ++ & ++ & - \\
\hline & Colletotrichum gloeosporioides (NEHU. ANSRJ.3) & ++ & - & + & +++ & ++ & + \\
\hline \multirow[t]{2}{*}{ Plants } & Garcinia xanthochymus H. & - & + & + & - & ++ & - \\
\hline & Polygonum chinense L. & - & - & + & - & ++ & - \\
\hline
\end{tabular}

$+++=$ Highly intense; $++=$ Intense; $+=$ Less intense. 

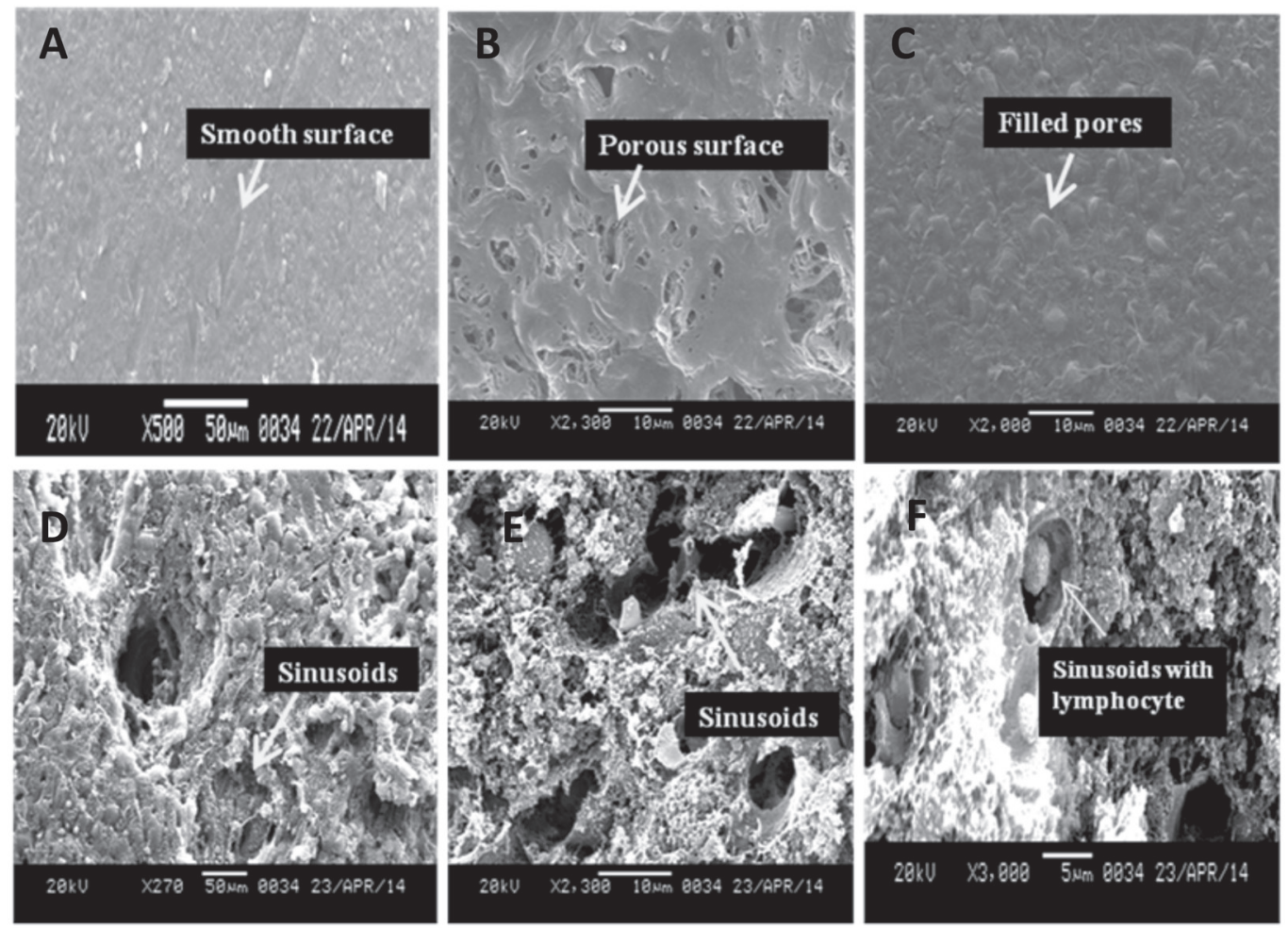

Fig. 2. Scanning electron micrographs of the liver of mice infected with Pasteurella multocida. A. Liver surface of the noninfected control group; B. Liver surface of the group infected with the bacteria but without treatment; C. Liver surface of the group infected with the bacteria and received treatment with the fungal extract of Glomerella magna; D. Liver surface of the non-infected control group with small sinusoids gaps; E. Large sinusoidal gaps are seen in the infected group of animals; F. Smaller sinusoids gaps are found in fungal extract treated group.

Carbolic acid (Fig. 4). The other extracts did not show the presence of carbolic acid.

\section{DISCUSSION}

Ethnoveterinary medicine has been in practice by the ethnic communities since ancient times for the treatment of various livestock diseases. Until today, these traditional practices using plants are used in rural and peri-urban regions of many growing nations including India. The local healers who are knowledgeable and experienced in traditional veterinary health care use the locally available plants (Balaji \& Chakravarthi, 2010). There are studies on the ethnoveterinary plants and their bioactivity (Doss, Mubaracki, Vijayasanthi, \& Venkataswamy, 2012, Kalayou et al., 2012, Adamu et al., 2014), but the medicinal value of the endophytic fungi associated with these plants is very scarce (Nath \& Joshi, 2014). Realizing the importance of ethnoveterinary practices and dwindling population of ethnoveterinary plants, bioactivity efficacy of endophytic fungi associated with these plants was explored in the present study to assess the potential of using the fungi as nanofactories for animal healthcare. The fungal extracts were found to show better antimicrobial activity than the plant extracts. P. multocida is a dreadful disease of livestock infecting cattles and pigs (Ramdani, Dawkins, Johnson, Spencer, \& Adler, 1990). A study on the antibacterial activity of an endophytic fungi, Phoma sp. against $P$. multocida is reported to show an inhibition zone of 26.5 $\mathrm{mm}$ (Zhang et al., 2012). The present findings 

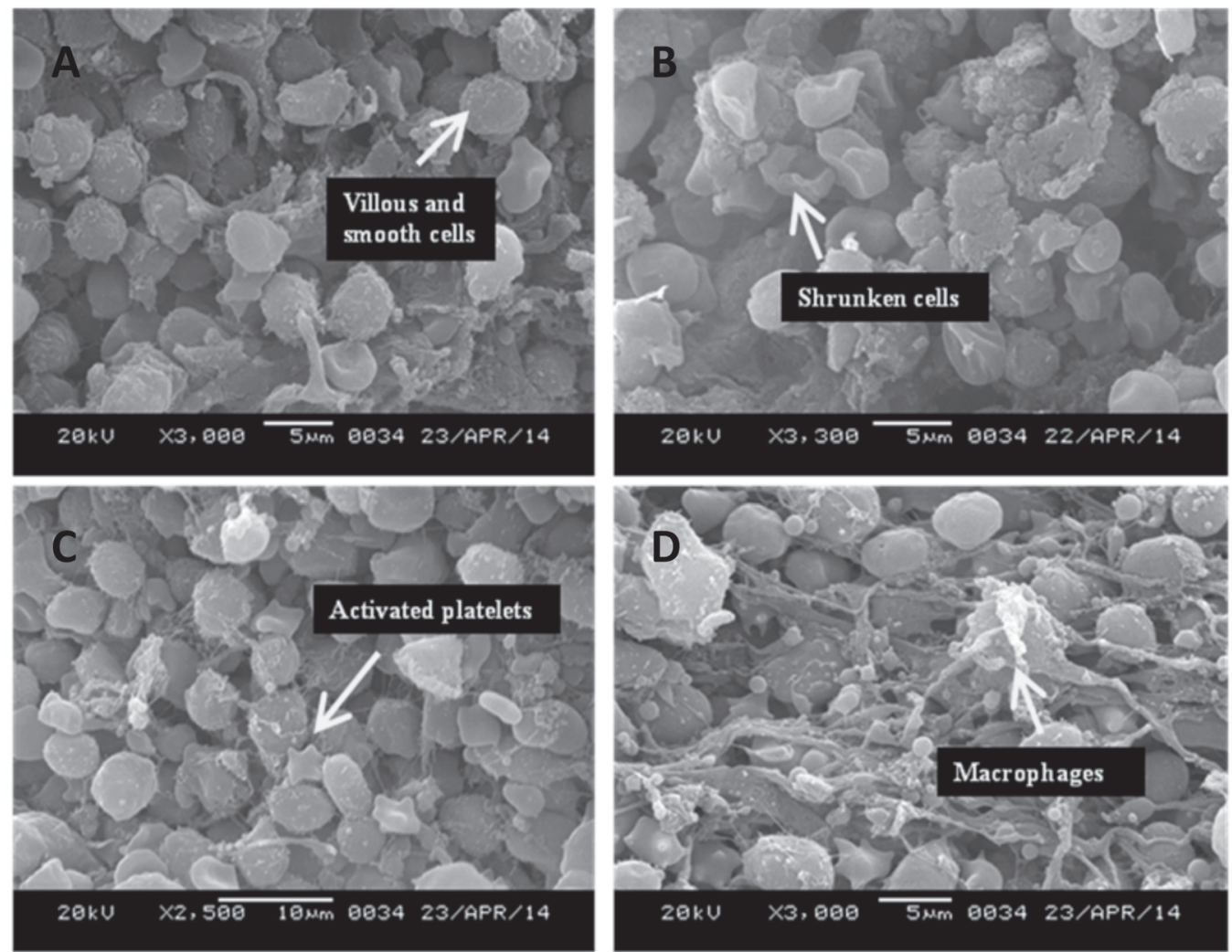

Fig. 3. Scanning electron micrographs of the spleen of mice infected with Pasteurella multocida . A. Scanning electron micrographs of spleen cells of normal control mice showing villous and smooth cells; B. Infected mice with Pasteurella multocida showing wrinkled and disintegrated spleen cells without any villi on their cell surface; $\mathbf{C}$. Treated group of mice with an extract of Glomerella magna, after infection with P. multocida showing presence of both normal and disintegrated type of spleen cells with presence of activated platelets; D. Treated group of mice showing presence of macrophages.

reveal G. magna showing significant antibacterial activity against $P$. multocida with an inhibition zone of $24 \mathrm{~mm}$. The extract of G. magna also showed lowest MIC $46.9 \mu \mathrm{g} / \mathrm{mL}$ and MBC $750 \mu \mathrm{g} / \mathrm{mL}$ which is in agreement with the result of well diffusion assay. The potency of G. magna against this pathogen observed in the study is attributed to the presence of effective antimicrobial agents in the endophytic fungal extract. Among all the endophytes and plant extracts, the most potent endophyte, $G$. magna, was then subjected to in vivo assays to assess its efficacy in an animal model, in cognizance to the artificial systemic infection of P. multocida in mice (Ramdani et al., 1990). In vivo antibacterial activity of the extract of $G$. magna exhibited noteworthy results in terms of low CFU/mL of vital organs, and reduced pathological conditions in liver and spleen in $P$. multocida infected animals which support the results of in vitro assays. The fungal extract of G. magna also showed the presence of phytochemicals like flavonoids, steroids, phenol and tannins which are known to have antimicrobial properties (Okwu \& Josiah, 2006). Similar to plant extracts, endophytic fungal extracts were rich in phytochemicals which contribute towards their bioactivity (Nath et al., 2012; Prabavathy \& Valli, 2013).

Carbolic acid has a history of being used as an antiseptic and sterilizing agent in operation theaters and hospitals (Sapna, Majumdar, 

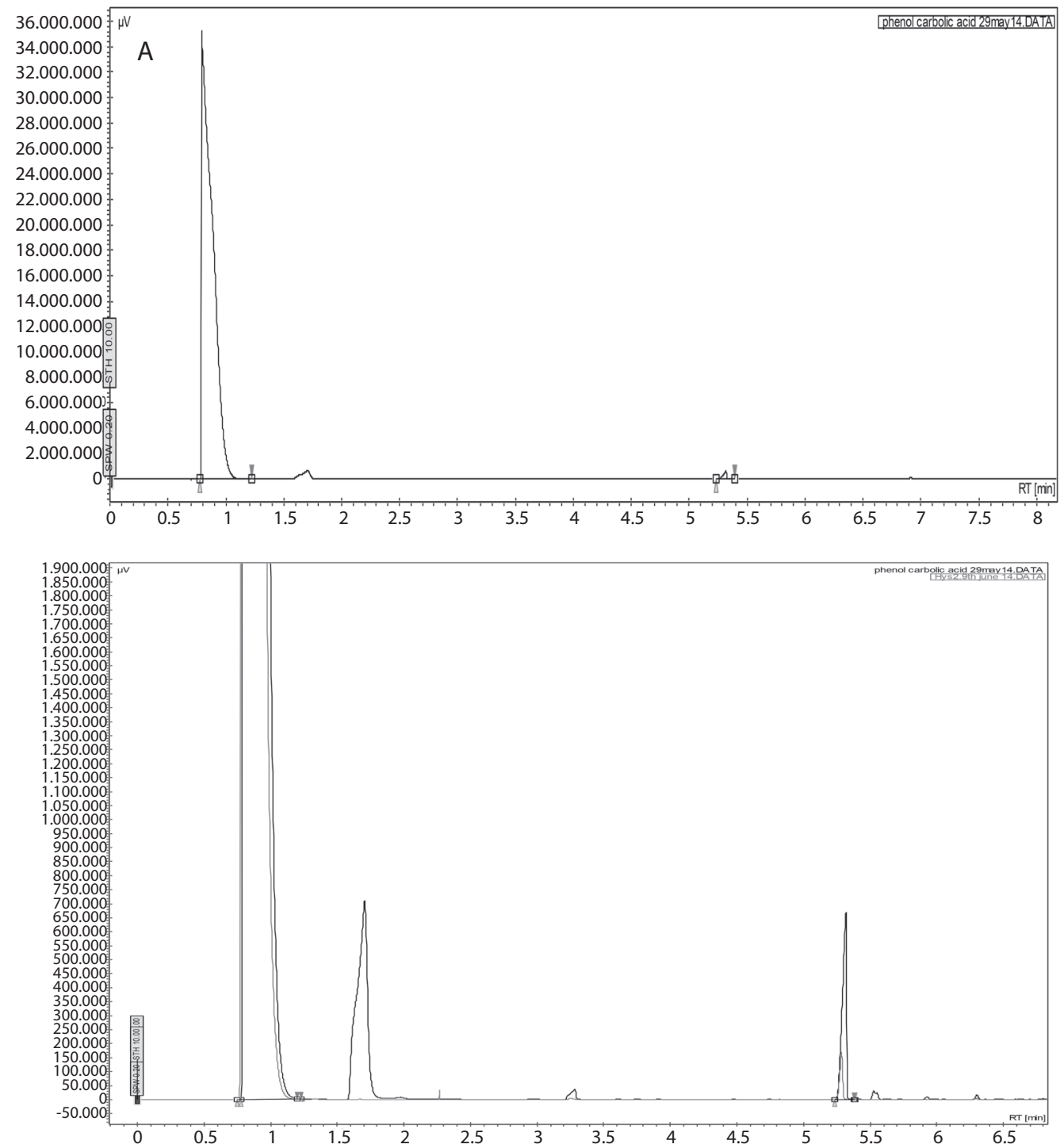

Fig. 4. GC chromatograms representing standard and crude extract of endophytic fungi. A. Standard Carbolic acid (phenol); B. Overlapped chromatogram of extract of Glomerella magna with standard.

\& Venkatesh, 2011). Phenol in low concentration is used as an antimicrobial agent and is also used in preparation of numerous pharmaceutical drugs (Cooper, 2004). Among all the extracts, G. magna showed the presence of carbolic acid (Phenol) with a retention time of 5.3 min in gas chromatography (GC) analysis. The potent antimicrobial activity of the extract may be due to the presence of carbolic acid. It was found that G. magna had significant presence of phenol in phytochemical screening which was confirmed by GC analysis. The observed bioactivity of the endophytic fungus leads to the conclusion that $G$. magna has potential as antibacterial agent to treat $P$. multocida infections. Further isolation of bioactive components 
could possibly bioprospect the pharmacological properties of G. magna metabolites and open vision for veterinary usage.

\section{ACKNOWLEDGMENTS}

The authors acknowledge the financial support received from Department of Biotechnology, Government of India in the form of research grant. The facility availed from SAIF, North-Eastern Hill University, and Shillong for using the scanning electron microscopy and partial support from DST-PURSE programme is gratefully acknowledged. Authors also acknowledge College of Veterinary science, Guwahati, Assam for providing the Pasteurella multocida cultures.

\section{RESUMEN}

Hongos endófitos de plantas tropicales etnoveterinarias y su eficacia antibacteriana contra cepas capsulares de Pasteurella multocida tipo A. Pasteurella multocida es un importante patógeno veterinario que causa infecciones en animales y aves. Hoy en día, diferentes informes han descrito la gravedad de las infecciones, aumentando la resistencia de los microorganismos a los antibióticos, y la contribución de las prácticas etnoveterinarias hacia el tratamiento de diversas enfermedades de los animales. El objetivo del presente estudio fue investigar la eficacia antibacteriana de los extractos etanólicos de hongos endófitos contra cepas de P. multocida tipo capsular A. Un total de seis hongos endófitos fueron aisladas de dos plantas etnoveterinarias tropicales: Garcinia xanthochymus $\mathrm{H}$. y Polygonum chinense L. Los extractos etanólicos de los hongos endófitos fueron sometidos a la actividad antimicrobiana in vitro por el método de difusión. Además, se evaluó el tratamiento de ratones con el extracto de hongos potente y observamos los efectos en diferentes órganos bajo el microscopio electrónico. Nuestros resultados mostraron que cuatro hongos tenían actividad antimicrobiana contra el patógeno seleccionado. La mejor actividad antibacteriana la mostró el extracto de los hongos endófitos, Glomerella magna aislado de G. xanthochymus, con una concentración inhibitoria mínima de $46.9 \mathrm{mg} / \mathrm{ml}$ y la concentración bactericida mínima de $750 \mathrm{mg} / \mathrm{ml}$. El tratamiento de ratones con el extracto de hongos potente causó un considerable efecto inhibidor sobre el crecimiento de patógenos en órganos vitales, resultados que también fueron confirmados por estudios histopatológicos realizados por microscopía electrónica de barrido. Los presentes hallazgos indican que el hongos endófitos G. magna tienen el potencial de proporcionar un tratamiento eficaz contra las infecciones causadas por Pasteurella multocida. Sin embargo, el aislamiento de componentes bioactivos necesita más investigación.

Palabras clave: plantas etnoveterinarias, hongos endófitos, antibacterianos, Pasteurella multocida, microscopía electrónica de barrido.

\section{REFERENCES}

Adamu, M., Naidoo, V., \& Eloff, J. N. (2014). The antibacterial activity, antioxidant activity and selectivity index of leaf extracts of thirteen South African tree species used in ethnoveterinary medicine to treat helminth infections. BMC Veterinary Research, 10, 52.

Akinyemi, K. O., Oladapo, O., Okwara, C. E., Ibe, C. C., \& Fasure, K. A. (2005). Screening of crude extracts of six medicinal plants used in South-West Nigerian unorthodox medicine for anti-methicillin resistant Staphylococcus aureus activity. BMC Complementary and Alternative Medicine, 5, 6 .

Bacon, C. W., \& White, J. F. (2000). Microbial endophytes. New York: Marcel Dekker.

Balaji, S. N., \& Chakravarthi, V. P. (2010). Ethnoveterinary Practices in India-A review. Veterinary World, 3, 549-551.

Bhagobaty, R. K., Joshi, S. R., \& Kumar, R. (2010). Penicillium verruculosum RS7PF: a root fungal endophyte associated with an ethno-medicinal plant of the indigenous tribes of eastern India. African Journal Microbiological Research, 4, 766-770.

Bhagobaty, R. K., \& Joshi, S. R. (2011a). Metabolite profiling of endophytic fungal isolates of five ethnopharmacologically important plants of Meghalaya, India. Journal of Metabolomics and System Biology, 2, 20-31.

Bhagobaty, R. K., \& Joshi, S. R. (2011b). Multi-loci molecular characterization of endophytic fungi isolated from five medicinal plants of Meghalaya, India. Mycobiology, 39, 71-78.

Cooper, R. (2004). A review of the evidence for the use of topical antimicrobial agents in wound care. World Wide wounds, February: 1-11. Downloaded from http://www.worldwidewounds.com/2004/february/ Cooper/Topical-Antimicrobial Agents.html

Doss, A., Mubaracki, H. M., Vijayasanthi, M., \& Venkataswamy, R. (2012). In-vitro antibacterial activity of certain wild medicinal plants against bovine mastitis isolated contagious pathogens. Asian Journal of Pharmaceutical Clinical Research, 5, 90-93.

Ecobichon, D. J. (1997). The Basis of Toxicology Testing $3^{\text {rd }}$ Edition). New York, USA: CRC Press. 
Edeoga, H. O., Okwu, D. E., \& Mbaebie, B. O. (2005). Phytochemical constituents of some Nigerian medicinal plants. African Journal of Biotechnology, 4, 685-688.

Ismail, I. F., Golbabapour, S., Hassandarvish, P., Hajrezaie, M., Majid, N. A., Kadir, F. A., ... Abdulla, M. A. (2012). Gastroprotective activity of Polygonum chinense aqueous leaf extract on ethanol-induced hemorrhagic mucosal lesions in rats. Journal of Evidence Based Complementary Alternative Medicine, 1-9.

Kalayou, S., Haileselassie, M., Gebre-Egziabher, G., Tiku'e, T., Sahle, S., \& Ghezu, M. (2012). In-vitro antimicrobial activity screening of some ethnoveterinary medicinal plants traditionally used against mastitis, wound and gastrointestinal tract complication in Tigray Region, Ethiopia. Asian Pacific Journal of Tropical Biomedicine, 2, 516-22.

Lulekal, E., Asfaw, Z., Kelbessa, E., \& Damme, P. V. (2014). Ethnoveterinary plants of Ankober District, North Shewa Zone, Amhara Region, Ethiopia. Journal of Ethnobiology and Ethnomedicine, 10, 21.

Lyngwi, L. A., Koijam, K., Sharma, D., \& Joshi, S. R. (2013). Cultivable bacterial diversity along the altitudinal zonation and vegetation range of tropical Eastern Himalaya. Revista de Biología Tropical, 61, 467-490.

Maharajan, M., Rajendran, A., Thomas, B., \& Aravindhan, V. (2012). Antibacterial and antifungal activities of Polygonum chinense Linn. Asian Journal of Plant Science Research, 2, 577-580.

Muharni, M., Elfita, E., \& Amanda, A. (2011). Biflavonoid compound from the stem bark of Gamboge (Garcinia xanthochymus). Indonesian Journal of Chemistry, 11, 169-173.

Myers, N., Mittermeier, R. A., Mittermeier, C. G., de Fonseca, G. A., \& Kent, J. (2000) Biodiversity hotspots for conservation priorities. Nature, 403, 853-8.

Nath, A., Raghunatha, P., \& Joshi, S. R. (2012). Diversity and biological activities of endophytic fungi of Emblica officinalis, an ethnomedicinal plant of India. Mycobiology, 40, 18-30.

Nath, A., \& Joshi, S. R. (2013). Bioactivity assessment of endophytic fungi associated with the ethnomedicinal plant Potentilla fulgens. World Journal of Pharmaceutical Research, 2, 2596-2607.

Nath, A., Chattopadhyay, A., \& Joshi, S. R. (2013). Biological activity of endophytic fungi of Rauwolfia serpentina Benth: An ethnomedicinal plant used in folk medicines in Northeast India. Proceedings of National Academy Sciences, India, Biological sciences, 85(1), 1-10.

Nath, A., \& Joshi, S. R. (2014). Ultrastructural effect on mastitis pathogens by extract of endophytic fungi associated with ethnoveterinary plant Hibiscus sabdariffa L. Journal of Microscopy and Ultrastructure, 3, 38-43.

NCCLS (National Committee for Clinical Laboratory Standards). (1990). Approved Standard, NCCLS M7-A2. Villanova, PA, USA.

NCCLS (National Committee for Clinical Laboratory Standards) (2002). Approved Standard, NCCLS M38-A. Villanova, PA, USA.

Okwu, D. E., \& Josiah, C. (2006). Evaluation of the chemical composition of two Nigerian medicinal plants. African Journal of Biotechnology, 5, 257-361.

Owais, M., Sharad, K. S., Shehbaz, A., \& Saleemuddin, M. (2005). Antibacterial efficacy of Withania somnifera (Ashwagandha) an indigenous medicinal plant against experimental murine salmonellosis. Phytomedicine, 12, 229-235.

Petrini, O. (1986). Taxonomy of endophytic fungi of aerial plant tissues. In N. J. Fokkenna \& J. Van Den Heuvel (Eds.), Microbiology of the phylosphere (pp. 175187). Cambridge: Cambridge University Press.

Prabavathy, D., \& Valli, N. C. (2013). Cytotoxic potential and phytochemical analysis of Justicia beddomei and its endophytic Aspergillus sp. Asian Journal of Pharmaceutical Clinical Research, 6, 159-161.

Ramdani, Dawkins, H. J. S., Johnson, R. B., Spencer, T. L., \& Adler, B. (1990). Pasteurella multocida infections in mice with reference to Haemorrhagic Septicaemia in cattle and buffalo. Immunology and Cell Biology, $68,57-61$.

Sapna, Majumdar, S., \& Venkatesh, P. (2011). The Operation Theatre: Basic Architecture. Delhi Journal of Ophthalmology, 21, 9-14.

Savaroglu, F., Ișcen, C. F., Vatan, A. P. O., Kabadere, S., IIhan, S., \& Uyar, R. (2011). Determination of antimicrobial and antiproliferative activities of the aquatic moss Fontinalis antipyretica Hedw. Turkish Journal of Biology, 35, 361-369.

Sofowora, A. (1993). Medicinal plants and Traditional medicine in Africa. Ibadan, Nigeria: Spectrum Books.

Strobel, G., Daisy, B., Castillo, U., \& Harper, J. (2004). Natural products from endophytic microorganisms. Journal of Natural Products, 67, 257-268.

Sweeney, M. T., Quesnell, R., Tiwari, R., LeMay, M., \& Watts, J. L. (2013). In vitro activity and rodent efficacy of clinafloxacin for bovine and swine respiratory disease. Frontiers of Microbiology, 4, 154.

Tabatabaei, M., Liu, Z., Finucane, A., Parton, R., \& Coote, J. (2002). Protective immunity conferred by attenuated aroA derivatives of Pasteurella multocida $\mathrm{B}: 2$ 
strains in a mouse model of hemorrhagic septicemia. Infection and Immunity, 70, 33-55.

Tamura, K., Peterson, D., Peterson, N., Stecher, G., Nei, M., \& Kumar, S. (2011). MEGA5: molecular evolutionary genetics analysis using maximum likelihood, evolutionary distance, and maximum parsimony methods. Molecular Biology Evolution, 28, 2732-2739.

Verma, V. C., Kharmar, R. N., \& Strobel, G. A. (2009). Chemical and functional diversity of natural products from plant associated endophytic fungi. Natural Product Communication, 4, 1511-1532.

Vijayarathna, S., Zakaria, Z., Chen, Y., Latha, L. Y., Kanwar, J. R., \& Sasidharan, S. (2012). The antimicrobial efficacy of Elaeis guineensis: characterization, in vitro and in vivo studies. Molecules, 17, 4860-4877.
World Assembly of Delegates of the OIE. (2012). Atrophic rhinitis of swine OIE terrestrial Manual (Chapter 2.8.2). Paris: OIE.

Yigezu, Y., Haile, D. B., \& Ayen, W. Y. (2014). Ethnoveterinary medicines in four districts of Jimma zone, Ethiopia: cross sectional survey for plant species and mode of use. BMC Veterinary Research, 10, 76.

Zhang, H. W., Song, Y. C., \& Tan, R. X. (2006). Biology and chemistry of endophytes. Natural Product Reports, 23, 753-771.

Zhang, H., Xiong, Y., Zhao, H., Yi, Y., Zhang, C., Yu, C., \& $\mathrm{Xu}, \mathrm{C}$. (2012). An antimicrobial compound from the endophytic fungus Phoma sp. isolated from the medicinal plant Taraxacum mongolicum. Journal of the Taiwan Institute of Chemical Engineers, 44, 177-181. 
